\title{
The Cytology of Smooth and Rough Variation in Bacteria
}

\author{
By K. A. BISSET \\ Department of Bacteriology, University of Birmingham
}

SUMMARY: In those members of the genera Bacterium and Bacillus studied, the constituent bacteria of Smooth cultures are typically unicellular, containing two chromatinic bodies. On division, a membranous septum is first formed, the bacillus subsequently dividing by constriction at this point.

The constituent bacteria of Rough cultures may comprise several cellular units, typically four, each containing a single chromatinic body and separated by membranous septa which, as growth proceeds, are transformed into true cell-wall septa, by the splitting of which the bacillus divides.

In previous papers (Bisset, 1938, 1939 $a, b$ ) I described the structure of Rough and Smooth colonies, and the characteristics of the constituent bacteria. The structure of a Rough colony is that of the 'Medusa-head' colony of Bacillus anthracis, and the bacilli tend to be longer, and squarer at the ends, than do those of a Smooth colony, which is relatively structureless, and in which the bacilli lie separately. At cell division, transverse septa were observable in the unstained condition, only in Rough forms, the Smooth forms appeared to divide by constriction (Bisset, 1939a).

The present study is intended to extend these observations, and especially to discover, in these variants, the behaviour of the chromatinic bodies (Badian, 1933; Piekarski, 1938, 1939; Robinow, 1942, 1944, 1945).

\section{METHODS}

The strains employed were Gram-negative intestinal bacteria of various species including Bacterium coli, isolated during routine examinations of faeces. These were usually Smooth on isolation, and dissociation was induced in them by growth in meat broth for periods of a week or more, and subculture upon agar. Stock cultures of this type of organism were usually Rough. Grampositive, sporing bacilli were isolated from dust in the laboratory, and were either Smooth or Rough upon isolation. Preparations were made from cultures aged 2-10 hr., grown aerobically upon nutrient agar at $37^{\circ}$.

At first, several methods of staining were tried, but the osmic acid fixation, acid-Giemsa staining, and Tannic-acid-violet techniques of Robinow (1945) were found to be best, especially for photography, and were eventually employed almost exclusively. The chromatinic bodies and cell membranes can, however, be demonstrated by many of the usual cytological staining techniques, especially by iron-alum haematoxylin. Water mounts were always employed for photography.

In the study of the Gram-negative bacteria of intestinal origin it was noticeable that the Smooth and Rough strains differed greatly in their staining reactions. Using the acid-Giemsa technique Smooth strains required only about $10 \mathrm{~min}$. in $\mathrm{N}-\mathrm{HCl}$ at $60^{\circ}$, and $0.75 \mathrm{hr}$. in the staining solution at $37^{\circ}$; 
whereas Rough strains required from 0.5 to more than $1 \mathrm{hr}$. in the acid and then up to $5 \mathrm{hr}$. in the staining solution. Too short a period in the acid resulted in a uniform violet appearance when stained. The bodies were seen most clearly after about $3 \mathrm{hr}$. incubation for Smooth strains and about $5 \mathrm{hr}$. for Rough.

\section{RESULTS}

The observations which were made agree, for the most part, with those of Robinow (1945), but as the author's interpretation is somewhat different, a full description is given.

When stained by acid-Giemsa, the appearance of the two forms of the intestinal bacteria was quite distinct. The Smooth bacilli normally contained two chromatinic bodies, division of which usually preceded that of the cell, producing four bodies distinctly arranged in pairs. Between the two pairs of bodies, at the point of division of the bacillus, a septum, staining clearly with acid-Giemsa, was sometimes seen (Pl. 1, fig. 1 $a$ ), and usually some degree of constriction was also visible at the point of division.

In the Rough forms there were usually four chromatinic bodies. The bacilli divided after the division of the bodies, and the point of division was marked, long before actual separation, by an unstained gap, which, as transpired subsequently, represented a septum, continuous with the cell wall and unstainable by Giemsa ( $\mathrm{Pl}$. 1, fig. $2 b$ ). The two halves of the bacillus were subdivided by septa which resembled those of the Smooth forms, and stained distinctly by Giemsa (Pl. 1, fig. 2a). Thus the Rough bacilli were, in fact, four-celled, and each cell was occupied by a single chromatinic body, sometimes in process of division.

A large number of strains of Gram-positive sporing aerobes were also examined. The genus Bacillus is peculiar in that its members are naturally either of Rough or Smooth morphology. The author has never observed this type of variation to occur spontaneously in the group. Of the 40 strains examined, all the large-celled species were of Rough morphology, and produced 'Medusa-head' colonies, some of the small-celled species were Rough, and some Smooth.

The structure of the Rough intestinal bacteria was repeated with great clarity in these Rough Bacillaceae. The unit was a bacillus containing four chromatinic bodies, each divided from the next by a septum (Pl. 1, fig. 3). Division of the bacilli occurred at the middle septum, immediately after, or during the division of the four chromatinic bodies into eight. Bacillaceae of Smooth morphology also resembled Smooth intestinal bacteria, except that the chromatinic bodies were smaller in proportion to the size of the bacilli, which were also longer in proportion to their breadth.

When the various types of bacteria were stained with tannic-acid-violet to demonstrate the cell walls, an entirely different appearance resulted. In the Smooth forms, only the cell outline was stainable, sometimes showing constriction at the point of division (Pl. 1, fig. 4; Pl. 2, fig. 5). The septa, which stained clearly with acid-Giemsa, did not appear at all by this method, 
indicating that they were not of the same material as the cell wall, and were probably derived from the cell membrane. In the Rough forms stained by tannicacid-violet it was obvious that the central division, an unstained gap in Giemsa preparations, was occupied by a septum continuous with the cell wall (Pl. 2, figs. 6, 7). The subsidiary septa, which stained with Giemsa, showed as faint shadows, presumably representing partial secretion of cell wall material within their thickness. No evidence either of centrifugal or centripetal 'iris diaphragm' formation of the new cell walls was observed. In these cells division was indicated by a slight indentation in the sides of the bacillus at the completed septum. There was no considerable degree of constriction.

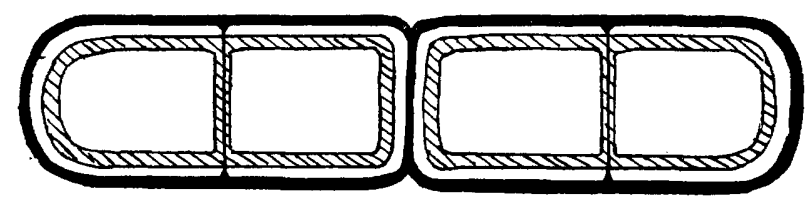

1. Rough variant

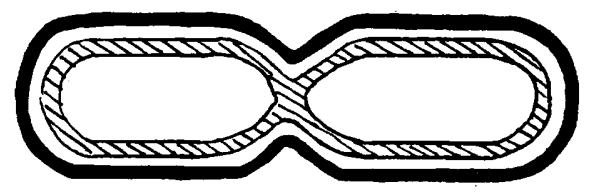

2. Smooth variant

Figs. 1 and 2. Membranes in dividing cells of Rough and Smooth variants. The cell wall is shown by heavy line, the cell membrane by hatched line.

\section{DISCUSSION}

The division of certain bacteria by septa staining well with basic dyes in their young stages, and of others by constriction, was recorded by Schaudinn $(1902,1903)$ and by many subsequent workers. The occurrence of multicellular bacteria is also fully established and has been well described by Robinow (1945) for some of the larger species. The process of cell division appears to occur in two main stages: first the formation of a transient septum, stainable with Giemsa, and presumably continuous with the cell membrane. The new cell wall forming the ends of the divided bacillus is then secreted by this membrane, but the manner in which this is accomplished differs in the two types of cell. In Rough bacilli the membranous septum is formed long before actual division occurs, two of the three partitions in a four-celled bacillus are of this nature (Figs. 1 and 3-6). The third, central partition is a true septum, continuous with the cell wall, and is secreted within the membranous septum. It is not stained by 'nuclear' dyes and the appearance of a fine, unstained line within the thickness of the strongly staining membranous septum is clearly shown in Schaudinn's illustrations. More recently it has been clearly described by Knaysi (1930). It is also visible in the unstained condition 
(Bisset, 1939a). As the two new bacilli separate, a very slight degree of constriction accompanies the division of this septum. It has not as yet proved possible to determine whether the septum, as originally formed, is single or double, but its thickness does not appear to be greater than that of the cell wall. The claims of workers, from Schaudinn onwards, that transverse septa are formed either by a centripetal ingrowth or by a centrifugal outgrowth, are not supported by this work. The first appearance of the new cell walls was as shadows within the membranous septa, and occupying their entire area (Pl. 2, figs. 6,7 ). This suggests that the former is composed of cell wall material

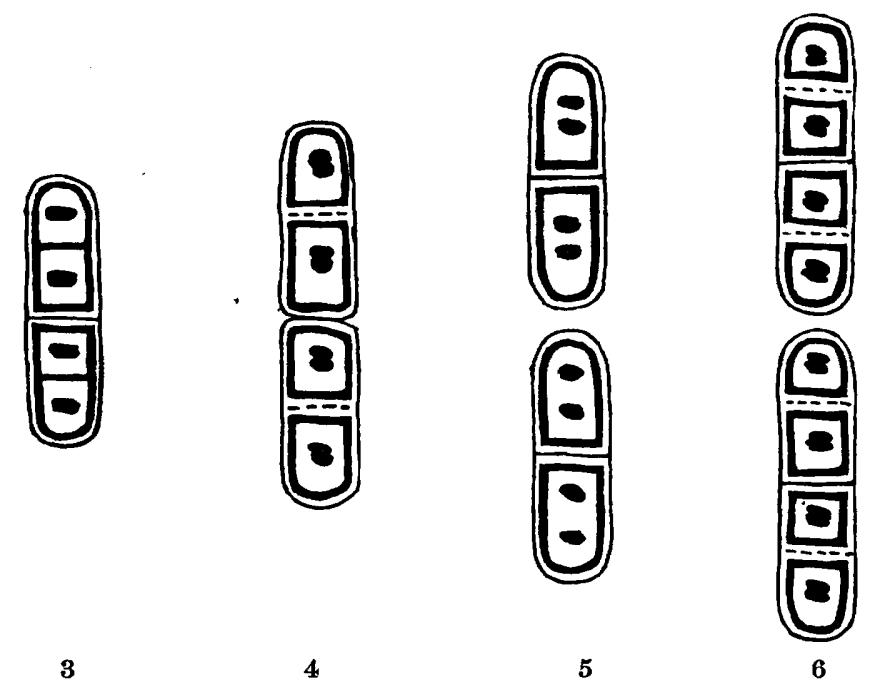

Figs. 3-6. Cell division in a Rough variant. The cell wall is shown by fine external line, the cell membrane by heavy line.

secreted internally by the latter, exactly as transverse cell walls are reported to be formed in higher plants (Martens, 1937). In Smooth forms the membranous septum is formed immediately before the division of the unicellular bacillus, and instead of secreting an entire, new cell wall, in one piece, the existing cell wall grows inward, by constriction, to form the ends of the new cells (Figs. 2 and 7-10). Presumably this extension is secreted by the membranous septum, as is the cell wall by the cell membrane. This process also is clearly shown in Schaudinn's figures.

Robinow (1945) appears to have observed cell division by septation in a Rough Bacillus sp. and by constriction in a Smooth Bacterium sp., and to have assumed that these modes of division were respectively characteristic of the two groups of bacteria.

It has been suggested that the different degree of apparent constriction shown by the two types at the actual separation of the daughter bacilli, may be due to the more voluminous 'slime layer' of the Smooth forms, which forces apart the newly formed surfaces (Dr J. P. Duguid, personal communication).

Interpretation of the behaviour of the chromatinic bodies is less obvious. It 
is exceedingly difficult to judge the exact condition of a rapidly growing organism which can justifiably be considered to be the resting stage. In both types the bodies usually divide immediately before the bacillus, although exceptionally they may do so afterwards, and if the condition immediately after division is to be taken as the criterion of chromosome arrangement, then the Rough bacillus may be considered as possessing two cells, each with two chromosomes, exactly as in the unicellular Smooth bacillus. However, in any preparation of a Rough culture, the great majority of organisms appear to be in the four-celled condition, each of the original chromosome pairs being

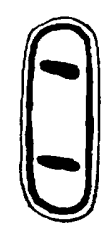

7

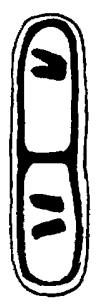

8

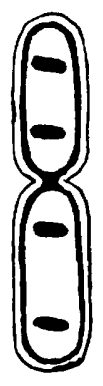

9
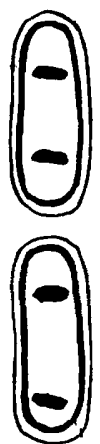

10

Figs. 7-10. Cell division in a Smooth variant. The cell wall is shown by fine external line, the cell membrane by heavy line.

separated by a membranous septum and the entire bacillus halved by the new cell wall. At this stage the chromosomes proceed to divide, giving a total number of eight, before the division of the bacillus.

Chromosome changes in bacteria have been observed before. The suggestion of chromosome reduction in connexion with sporulation has several times been made (Badian, 1933; Allen, Appleby \& Wolf, 1939; Klieneberger-Nobel, 1945). The appearances recorded here, however, occur equally in sporing and non-sporing genera.

The parallel between colony structure of Smooth and Rough variants in the Bacteriaceae and that of the two morphological types in the Bacilaceae is shown to be based upon strong resemblances in minute structure. The significance of the variation, however, is still to seek.

\section{REFERENCES}

Allen, L. A., Appleby, J. C. \& Wolf, J. (1939). Cytological appearances in a sporeforming bacillus. Evidence of meiosis. Z Zbl. Bakt. (2. Abt.), 100, 3.

Badian, J. (1933). Eine cytologische Untersuchung über das Chromatin und den Entwicklungzyklus der Bakterien. Arch. Mikrobiol. 4, 409.

Bisser, K. A. (1938). The structure of 'rough' and 'smooth' colonies. J. Path. Bact. 47, 223.

Bisset, K. A. (1939a). The mode of growth of bacterial colonies. J. Path. Bact. 48, 427. 
Bisset, K. A. $(1939 b)$. The structure and mode of growth of bacterial colonies morphologically intermediate between $R$ and $S$ forms. $J$. Path. Bact. 49, 491.

KLIENEberger-Nobel, E. (1945). Changes in nuclear structure of bacteria, particularly during spore formation. J. Hyg., Camb., 44, 99.

Knaysi, G. (1930). Cell structure and cell division of Bacillus subtilis. J. Bact. 19, 113.

Martens, P. (1937). L'origine des espaces intercellulaires. Cellule, 46, 357.

Robinow, C. F. (1942). A study of the nuclear apparatus of bacteria. Proc. Roy. Soc. B, 130, 299.

Robinow, C. F. (1944). Cytological observations on Bact. coli, Proteus vulgaris and various aerobic spore-forming bacteria with special reference to the nuclear structures. J. Hyg., Camb., 43, 413.

Roвinow, C. F. (1945). Addendum to The Bacterial Cell, by Dubos, R. J. Cambridge, Mass.: Harvard University Press.

Prekarski, G. (1938). Zytologische Untersuchungen an Bakterien im ultravioletten Licht. Zbl. Bakt. (I. Abt. Orig.), 142, 69.

Piekarski, G. (1939). Lichtoptische und übermikroskopische Untersuchungen zum Problem des Bakterienzellkerns. Zbl. Bakt. (1. Abt. Orig.), 144, 140.

SchaudinN, F. (1902). Beiträge zur Kenntnis der Bakterien und verwandter Organismen. I. Bacillus bütschlii, n.sp. Arch. Protistenk. 1, 306.

SchaudinN, F. (1903). Beiträge zur Kenntnis der Bakterien und verwandter Organismen. II. Bacillus sporenema, n.sp. Arch. Protistenk. 2, 421.

\section{EXPLANATION OF PLATES}

$$
\text { All } \times 3000 \text {. }
$$

\section{Plate 1}

Fig. 1. Bact. coli, Smooth, acid-Giemsa. Bacteria at various stages of division; membranous septum at $a$. Several bacteria are in the resting condition.

Fig. 2. Bact. coli, Rough, acid-Giemsa. Membranous septum at $a$; septum at $b$ continuous with cell wall, showing unstained.

Fig. 3. Bacillus sp., Rough morphology, acid-Giemsa. Membranous and cell wall septa are clearly shown. Compare fig. 2.

Fig. 4. Bact. coli, Smooth, tannic-acid-violet, showing constriction of cell wall at point of division in numerous cases.

\section{Plate 2}

Fig. 5. Bacillus sp., Smooth morphology, tannic-acid-violet. Note the absence of transverse septa.

Fig. 6. Bact. coli, Rough, tannic-acid-violet. Note the transverse septa, and in right-hand bacillus, which is about to divide, the shadows of new septa forming. Compare fig. 2.

Fig. 7. Bacillus sp., Rough morphology, tannic-acid-violet. Note the transverse septa and the shadows of new septa forming in those about to divide. Compare fig. $\mathbf{3}$.

(Received 3 September 1947) 
Journal of General Microbiology, Vol. 2, No. 1

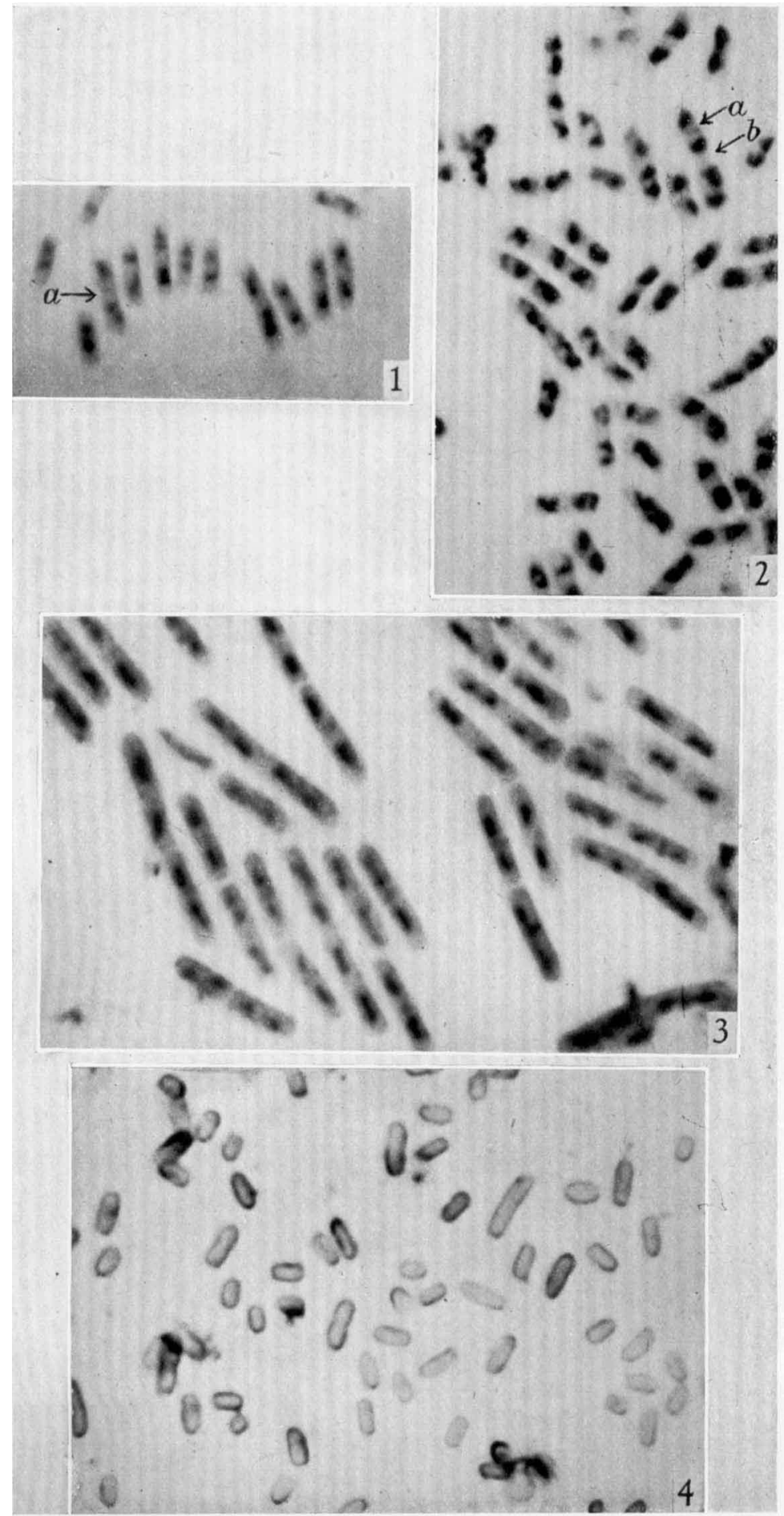

Figs. 1-4

K. A. Bisset-'Thle cy'rology of shooth and rough variation in bacteria. Plate 1 
Journal of General Microbiology, Vol. 2, No. 1
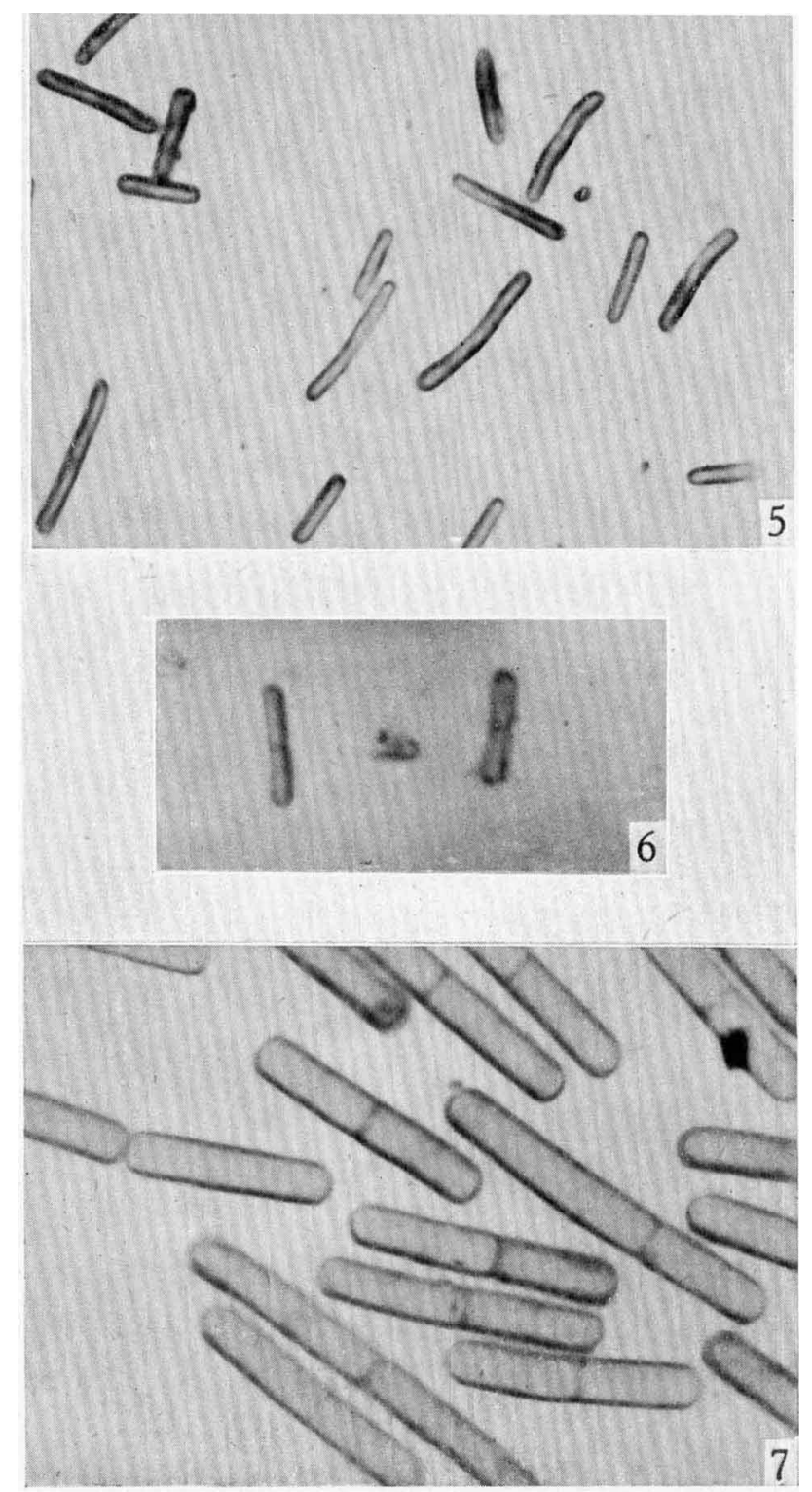

Figs. 5-7

K. A. Bisset-The cytology of SMooth and rough vartation in BaCterta. Plate 2 